\title{
PENGARUH METODE ROLE PLAYING / BERMAIN PERAN TERHADAP ASPEK PERKEMBANGAN BAHASA PADA ANAK
}

\author{
Ivonne Hafidlatil Kiromi*
}

\begin{abstract}
Game and play has its own meaning and meaning for the child. The game has a meaning as a means of self-socializing (children) means the game is used as a means of bringing children into society, knowing and appreciating the community. Role play is also called symbolic play, pretend, make-believe, imagination. This game is very important for the development of cognition, language, social, and emotion in early childhood. Language is one of the most important things in a child's life, with the child's language being able to interact with others and discover many new things in the environment. With language also, children are able to pour an idea or idea of his wishes. words to express ideas to others
\end{abstract}

Keywords: role playing, language aspect development.

\footnotetext{
* Dosen tetap Prodi PIAUD INZAH Genggong Kraksaan
} 


\section{A. Pendahuluan}

Bermain merupakan kegiatan yang sangat penting bagi tumbuh kembang anak. Bermain harus dilakukan atas inisiatif anak dan atas keputusan anak itu sendiri. Dalam melakukan kegiatan bermain, anak akan melakukannya dengan rasa senang, sehingga semua kegiatan bermain yang menyenangkan akan menghasilkan proses belajar pada anak.

Permainan dan bermain memiliki arti dan makna tersendiri bagi anak. Permainan memiliki arti sebagai sarana mensosialisasikan diri (anak) artinya permainan digunakan sebagai sarana membawa anak ke dalam masyarakat, mengenal dan menghargai masyarakat. Permainan sebagai sarana untuk mengukur kemampuan dan potensi diri anak.

Dalam situasi bermain anak akan dapat menunjukkan bakat, fantasi, dan kecendrungan-kecendrungannya. Saat bermain anak akan menghayati berbagai kondisi emosi yang mungkin muncul seperti rasa senang, gembira, tegang, kepuasan, dan mungkin rasa kecewa. Permainan merupakan alat pendidikan karena memberikan rasa kepuasan, kegembiraan, dan kebahagiaan.

Permainan dan bermain bagi anak memiliki beberapa fungsi dalam proses tumbuh kembang anak. Fungsi bermain terhadap sensoris motoris anak penting untuk mengembangkan otot-ototnya dan energi yang ada. Aktifitas sensoris motorik merupakan komponen yang paling besar pada semua usia, namun paling dominan pada bayi. Pada bayi seyogianya mendapatkan stimulasi visual, pendengaran (verbal), sentuhan (taktil), dan stimulasi kinestetis (gerak).

Bermain selain mengembangkan kemampuan sensoris motor anak, juga mempengaruhi segala aspek perkembangan pada anak, salah satunya pada perkembangan Bahasa. Perkembangan aspek Bahasa sangat erat kaitannya dengan perkembangan kemampuan intelektual dan social.

Menurut Jamaris (2002:113) komunikasi dan Bahasa merupakan dua aspek yang sangat penting dalam kehidupan manusia. Tanpa dua kemampuan ini, manusia akan kesulitan untuk melakukan interaksi social. Bahasa dapat di definisikan sebagai bentuk kode social yang memiliki system yang digunakan untuk berkomunikasi.

Bahasa merupakan alat untuk berfikir, mengekspresikan diri dan berkomunikasi. Ketermpilan Bahasa juga sangat penting dalam rangka pembentukan konsep, informasi, dan pemecahan masalah. Bahasa merupakan alat berkomunikasi dengan orang lain dan kemudian berlangsung dalam interaksi sosial.

\section{B. Pembahasan}




\section{Bermain Peran}

Bermain Peran merupakan bermain secara spontan, aktivitas mandiri, dan meningkatkan pemahaman mereka tentang diri sendiri dan dunia mereka. Walaupun permainan anak-anak memiliki variasi yang berbedabeda di setiap belahan dunia dan dalam budaya yang berbeda, akan tetapi tema permainan mereka sama. Dalam permainan mereka, anak-anak menciptakan tempat dan adegan yang sangat akrab dengan mereka, seperti menirukan adegan anggota keluarga,dan memerangkan peran yang yang berbeda-beda yang berada disekitar mereka.

Dari masa anak-anak awal, anak-anak menirukan suara yang mereka dengar dan melakukan akitifitas yang mereka lihat, dan anak-anak merespon terhadap situsai yang baru melalui gerakan dan suara. Ringkasnya, anak-anak bermain. Melalu bermain peran itulah, merupakan salah satu cara bagi anak-anak dalam mengeksplor dunia mereka, menirukan dengan cara beraksi dan menirukan karakter yang berada disekitar mereka.

Bermain peran merupakan bermain simbolis yang dimainkan oleh anak-anak. Sesuai yang teori Vygotsky dan Erikson (Mutiah, 2010:115) yang berpendapat bahwa main peran merupakan: "Main simbolis, purapura, make-believe, fantasi, imajinasi, atau main drama. Main peran sangat penting untuk perkembangan kognitif, sosial, dan emosi anak pada usia tiga sampai enam tahun".

Menurut Hamalik (2004:214) bahwa bermain peran adalah "model pembelajaran dengan cara memberikan peran-peran tertentu kepada peserta didik dan mendramatisasikan peran tersebut kedalam sebuah pentas". Bermain peran (role playing) adalahsalah satu model pembelajaran interaksi sosial yang menyediakan kesempatan kepada murid untuk melakukan kegiatan-kegiatan belajar secara aktif dengan personalisasi. Oleh karena itu, lebih lanjut Hamalik ${ }^{1}$ mengemukakan bahwa "bentuk pengajaran role playing memberikan pada murid seperangkat/serangkaian situasi-situasi belajar dalam bentuk keterlibatan pengalaman sesungguhnya yang dirancang oleh guru". Selain itu, role playing sering kali dimaksudkan sebagai suatu bentuk aktivitas dimana pembelajar membayangkan dirinya seolah-olah berada di luar kelas dan memainkan peran orang lain saat menggunakan bahasa tutur. ${ }^{2}$

\footnotetext{
${ }^{1}$ M. Jamaris, Perkembangan dan Pengembangan Anak Usia Taman Kanak-Kanak; Pedoman Bagi Orang Tua dan Guru. Jakarta: PT. Grasindo.

2004: 214

2 (Syamsu, 2000).
} 
Hakekat bermain peran terletak pada keterlibatan emosional pemeran dan pengamat dalam situasi masalah yang secara nyata dihadapi. Melalui bermain peran dalam pembelajaran, diharapkan para peserta didik dapat (1) mengeksplorasi perasaannya; (2) memperoleh wawasan tentang sikap, nilai, dan persepsinya; (3) mengembangkan keterampilan dan sikap dalam memecahkan masalah yang dihadapi; dan (4) mengeksplorasi inti permasalahan yang diperankan melalui berbagai cara.

Erik Erickson menjelaskan dua jenis tentang bermain peran, yaitu bermain peran bisa dilakukan dalam bentuk makro dan mikro. Yang dimaksud dengan bermain peran makro adalah anak yang berperan secara langsung dalam cerita tersebut. Saat anak melakukan main peran dalam bentuk makro atau yang bermain secara langsung, maka anak akan belajar banyak keterampilan pra akademis. Seperti, mampu memecahkan masalah, mendengarkan dan mampu bekerja sama dengan teman sebaya. ${ }^{3}$

Dan yang dimaksud dengan bermain peran mikro adalah merupakan kebalikan dari bermain peran makro. Yaitu dimana anak bermain tidak melibatkan secara langsung. Mereka bermain dengan menggunakan boneka, robot atau alat permainan lainnya. Pada saat anak bermain peran mikro maka anak akan belajar untuk menghubungkan alur cerita serta mengambil sudut pandang orang lain.

\section{a. Sentra Bermain Peran Besar (Makro)}

Sentra bermain peran besar adalah sentra yang memberikan kesempatan kepada anak untuk mengembangkan pengertian mereka tentang dunia disekitarnya, kemampuan berbahasa, keterampilan mengambil sudut pandang dan mepati melalui main peran yang mengalirkan knowledge kepada anak.

Alat/media bermain peran besar adalah alat dengan ukuran yang sesungguhnya. Artinya, alat tersebut bisa dipakai anak saat bermain. Perlengkapan dalam kegiatan bermain peran besar di bagi atas:

1) Alat dan bahan main kerumah tanggaan.

2) Alat dan bahan main keprofesian.

3) Alat dan bahan main yang mendukung keaksaraan.

Kegiatan yang dilakukan dalam sentra bermain peran besar adalah, dengan memainkan peran-peran yang terdapat di muka bumi yang berada disekitar anak-anak, seperti: peran ayah, ibu, dokter, binatangbinatang.

\section{b. Sentra Bermain Peran Kecil}

Bermain peran kecil (mikro) mengalirkan materi/knowledge pada anak melalui alat main yang berukuran kecil. Anak sebagai dalang

\footnotetext{
${ }^{3}$ Erik Erickson (1963)
} 
yang menggerakkan boneka yang menjadi pemeran. Alat dan bahan sentra bermain peran kecil dapat diklasifikasikanatau dikelompokkan sebagai berikut;

1) Maket bangunan berikut perlengkapan furniture dengan ukuran yang proposional dengan bangunannya, seperti rumah boneka, meja, kursi yang sesuai dengan ukuran rumah boneka

2) Boneka orang dan binatang

3) Aksesoris pendukung seperti, pohon, pagar, kendaraan, perlengkapan makan, perlengkapan memasak, perlengkapan yang berhubungan dengan peran profesi masing-masing.

4) Alat dan bahan main yang mendukung keaksaraan anak.

Dalam proses belajar dengan bermain peran, maka anak akan diajari untuk lebih percaya diri untuk mengeksplor bakatnya serta melatih agar mampu tampil dihadapan umum. Selain itu, terdapat beberapa manfaat dengan dilakukannya belajar dengan bermain peran. Yaitu:

1) Mengembangkan kreativitas dan pertumbuhan intelektual anak. Karena dengan melakukan main peran, anak akan tertantang untuk berfikir tentang tokoh yang akan diperankannya dan juga terangsang untuk mengeluarkan ide-ide baru.

2) Penyesuaian diri anak. Dengan memerankan tokoh-tokoh tertentu ia belajar tentang aturan-aturan atau perilaku apa yang mampu diterima oleh orang lain, baik dalam berperan sebagai ibu, ayah, guru, murid, dst. Anak juga belajar memandang masalah dari kaca mata tokohtokoh yang ia perankan sehingga diharapkan dapat membantu pemahaman social pada diri anak.

3) Meningkatkan kemampuan berbahasa. Mau tidak mau anak akan mendengarkan informasi baru, sehingga perbendaharaan kata pada anak akan semakin luas.

4) Belajar untuk mematuhi aturan yang berlaku. Kadang mungkin inisiatif untuk menjadi peran tertentu dipilihnya sendiri, tetapi kadang ia harus memerankan tokoh yang telah merupakan kesepakatan.

5) Memperoleh kesenangan dari kegiatan yang dilakukan.

6) Membantu anak menghubungkan dunia nyata dan imajinasi.

\section{Hakikat Perkembangan Bahasa}

Bahasa memungkinkan anak untuk menerjemahkan pengalaman ke dalam symbol-symbol yang dapat digunakan untuk berkomunikasi dan berpikir. Vygotsky dalam Wolfolk menyatakan bahwa: "language provide a means for expressing ideas and asking question and it provides 
the categories and concept for thinking". 4 Sejalan dengan pendapat Susanto mengungkapkan bahwa Bahasa adalah alat untuk berpikir, mengekspresikan diridan berkomunikasi.Keterampilan bahasa juga penting dalam rangka pembentukan konsep, informasi, dan pemecahan masalah. Melalui bahasa pula kita dapat memahami komunikasi pikiran dan perasaan, dengan bahasa anak dapat berinteraksi dengan orang lain dan menemukan banyak hal baru dalam lingkungan tersebut. Dengan bahasa juga anak mampu menuangkan suatu ide atau gagasan terhadap keinginannya tersebut. ${ }^{5}$

Perkembangan Bahasa dipengaruhi oleh lingkungan anak dan lingkungan sekitarnya. Interaksi dengan orang yang lebih dewasa atau penutur yang lebih matang memainkan peranan yang sangat penting dalam membantu peningkatan kemampuan anak untuk berkomunikasi. ${ }^{6}$

Dari beberapa teori diatas dapat disimpulkan, bahwasanya Bahasa memiliki peran yang sangat penting dalam perkembangan social anak. Perkembangan bahasa pada anak usia dini merupakan perubahan sistem lambang bunyi yang berpengaruh terhadap kemampuan berbicara anak, dalam hal dapat membantu anak untuk bekerja sama dengan lingkungannya, mampu mengungkapkan pendapatnya, serta mampu mengidentifiksi dirinya.

\section{Aspek-Aspek Perkembangan Bahasa Anak}

Aspek-aspek yang berkaitan dengan perkembangan bahasa anak menurut Jamaris dapat dibagi kedalam tiga aspek ${ }^{7}$, yaitu:

1. Kosakata. Seiring dengan perkembangan anak dan pengalamannya berinteraksi dengan lingkungan, kosakata anak berkembang dengan pesat.

2. Sintaksis (tata bahasa). Walaupun anak belum mempelajari tata bahasa, akan tetapi melalui contoh-contoh berbahasa yang didengar dan dilihat anak dilingkungannya, anak telah dapat menggunakan bahasa lisan dengan susunan kalimat yang baik.

\footnotetext{
${ }^{4}$ Ahmad Susanto, Perkembangan Anak Usia Dini. Jakarta: Kencana 2011: 73

${ }_{6}^{5}$ Ahmad Susanto 2011: 74 2016:41.

6 Lilis Madyawati, Strategi Pengembangan Bahasa Pada Anak. Jakarta: Kencana.
}

${ }^{7}$ Ahmad Susanto. 2011:77 
3. Semantik. Semantik maksudnya penggunakan kata sesuai dengan tujuannya. Anak ditaman kanak-kanak sudah dapat mengekspresikan keinginan, penolakan, dan pendapatnya dengan menggunakan katakata dan kalimat yang tepat.

Sesuai dengan pendapat Vygotsky tentang prinsip zone proximal, yaitu zona yang berkaitan dengan perubahan dari potensi yang dimiliki oleh anak menjadi kemampuan actual,maka prinsip-prinsip perkembangan bahasa anak usia taman kanak-kanak adalah ${ }^{8}$ :

1. Interaksi. Interaksi anak dengan lingkungan di sekitarnya, membantu anak memperluas kosakatanya dan memperoleh contoh-contoh dalam menggunakan kosakata ini secara tepat.

2. Ekspresi. Mengekspresikan kemampuan bahasa. Ekspresi kemampuan bahasa anak untuk mrngungkapkan pikiran dan perasaannya secara tepat.

\section{Fungsi Bahasa Bagi Anak Usia Dini}

Ada beberapa sumber yang telah mencoba memberikan penjabaran dari fungsi bahasa bagi anak taman kanak-kanak, menurut Depdiknas fungsi pengembangan bahasa bagi anak prasekolah adalah ${ }^{9}$ :

a. Untuk berkomunikasi dengan lingkungan

b. Sebagai alat untuk mengembangkan kemampuan intelektual anak

c. Sebagai alat untuk mengembangkan ekspresi anak

d. Sebagai alat untuk menyatakan perasaan dan buah pikiran kepada orang lain.

\section{Prinsip Pengembangan Bahasa Anak Usia Dini}

Sesuai tujuan dan fungsi yang dijabarkan maka dalam pelaksanaan upaya pengembangan bahasa untuk anak diperlukan beberapa prinsip dasar. Beberapa prinsip pengembangan bahasa yang disajikan oleh Depdiknas adalah $^{10}$ :

1. Sesuaikan dengan tema kegiatan dan lingkungan terdekat.

2. Pembelajaran harus berorientasi pada kemampuan yang hendak dicapai sesuai potensi anak.

3. Komunikasi guru dan anak akrab dan menyenangkan.

4. Guru menguasai pengembangan bahasa.

5. Diberikan alternative pikiran dalam mengungkapkan isi hatinya

\footnotetext{
${ }^{8}$ Ahmad Susanto. 2011:78

${ }^{9}$ Ahmad Susanto. 2011:81

${ }^{10}$ Ahmad Susanto. 2011:82
} 


\section{Tujuan Pengembangan Bahasa Anak Usia Dini}

Pengembangan keterampilan bahasa anak merupakan kemampuan yang sangat penting untuk berkomunikasi terutama bagi mereka yang sudah masuk ke lingkungan pendidikan prasekolah khususnya taman kanak-kanak. Tujuan pengembangan bahasa pada usia awal adalah :

1. Mendengarkan, menyimak, menggunakan bahasa lisan dan lebih siap dalam bermain dan belajarnya.

2. Menggunakan pembicaraan, untuk mengorganisasikan, mengurutkan, berpikir jelas, ide-ide, perasaan, dan kejadian-kejadian.

3. Merespons terhadap yang mereka dengan komentar, pertanyaan dan perbuataan yang relevan.

4. Memperluas kosakata mereka meneliti arti dan suara dari kata-kata baru.

5. Berbicara lebih jelas dan dapat didengar dengan kepercayaan dan pengawasan dan bagaimana memperlihatkan kesadaran pada pendengar.

\section{Karakteristik Kemampuan Bahasa Anak Usia Dini}

Menurut Jamaris karakteristik bahasa anak usia 5-6 tahun adalah : Sudah dapat mengucapkan lebih dari 2.500 kosakata Lingkup kosakata yang dapat diucapkan anak menyangkut warna, ukuran, perbandingan, jarak, dan permukaan (kasar-halus). Sudah dapat mengucapkan lebih dari 2.500 kosakata Dapat berpatisipasi dalam suatu percakapan. Anak sudah dapat mendengarkan orang lain berbicara dan menanggapi pembicaraan tersebut. Percakapan yang dilakukan oleh anak 5-6 tahun telah menyangkut berbagai komentarnya terhadapapa yang dilakukan oleh dirinya sendiri dan orang lain, serta apa yang dilihatnya. Anak pada usia 5-6 tahun ini sudah dapat melakukan ekspresi diri, menulis, membaca, dan bahkan berpuisi. ${ }^{11}$

\section{Penutup}

Bermain Peran merupakan bermain secara spontan, aktivitas mandiri, dan meningkatkan pemahaman mereka tentang diri sendiri dan dunia mereka. Dalam bermain peran, anak-anak menciptakan tempat dan adegan yang sangat akrab dengan mereka, seperti menirukan adegan anggota keluarga, dan memerangkan peran yang yang berbeda-beda yang berada disekitar mereka. Melalu bermain peran anak-anak dapat menambah kosa kata Bahasa itulah merupakan salah satu cara bagi anak-anak untuk berlatih komunikasi, bekerja sama, dan mengeksplor

\footnotetext{
${ }^{11}$ Ahmad Susanto. 2011: 78
} 
dunia mereka, menirukan dengan cara beraksi dan menirukan karakter yang berada disekitar mereka

\section{Daftar Pustaka}

Mutiah, Diana. 2010. Psikologi Bermain Anak Usia Dini.Jakarta: Kencana.

Latif, Mukhtar dkk. 2013. Orientasi Baru Pendidikan Anak Usia Dini.Jakarta: Kencana

Hamalik, O. 2004. Proses Belajar Mengajar. Bandung: Bumi Aksara.

Susanto, Ahmad. 2012. Perkembangan Anak Usia Dini. Jakarta: Kencana.

Madyawati, Lilis. 2016. Strategi Pengembangan Bahasa Pada Anak. Jakarta: Kencana.

Jamaris, M. 2002. Perkembangan dan Pengembangan Anak Usia Taman KanakKanak; Pedoman Bagi Orang Tua dan Guru. Jakarta: PT. Grasindo. 